\title{
BANCA D'ITALIA
}

E U R O S I S T E M A

\section{Temi di Discussione}

(Working Papers)

Informal loans, liquidity constraints and local credit supply: evidence from Italy

by Michele Benvenuti, Luca Casolaro and Emanuele Ciani 



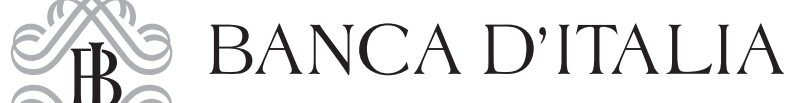

E U R O S I S T E M A

\section{Temi di discussione}

(Working papers)

Informal loans, liquidity constraints and local credit supply: evidence from Italy

by Michele Benvenuti, Luca Casolaro and Emanuele Ciani

Number 1099 - February 2017 
The purpose of the Temi di discussione series is to promote the circulation of working papers prepared within the Bank of Italy or presented in Bank seminars by outside economists with the aim of stimulating comments and suggestions.

The views expressed in the articles are those of the authors and do not involve the responsibility of the Bank.

Editorial Board: Ines Buono, Marco Casiraghi, Valentina Aprigliano, Nicola Branzoli, Francesco Caprioli, Emanuele Ciani, Vincenzo Cuciniello, Davide Delle Monache, Giuseppe Ilardi, Andrea Linarello, Juho Taneli Makinen, Valerio Nispi Landi, Lucia Paola Maria Rizzica, Massimiliano Stacchini.

Editorial Assistants: Roberto Marano, Nicoletta Olivanti.

ISSN 1594-7939 (print)

ISSN 2281-3950 (online)

Printed by the Printing and Publishing Division of the Bank of Italy 


\title{
INFORMAL LOANS, LIQUIDITY CONSTRAINTS AND LOCAL CREDIT SUPPLY: EVIDENCE FROM ITALY
}

\author{
by Michele Benvenuti*, Luca Casolaro**, and Emanuele Ciani***
}

\begin{abstract}
Using data from the Italian Survey on Household Income and Wealth from 1995 to 2014, we study the relation between informal credit (loans from relatives and friends) and a household's access to bank credit. While most of the literature has focused on the substitutability channel, we highlight that even households with full access to the formal credit market are more likely to be indebted to relatives or friends when compared to those not interested in formal loans. This complementarity is stronger for households who have problems paying back their loans, suggesting the presence of a caretaker effect on the part of relatives and friends towards distressed families. Finally, we estimate the overall impact of an expansion of local credit supply on the diffusion of informal loans, using an IV approach. The results suggest that the complementarity effect prevails, but the positive effect on informal loans is economically very small.
\end{abstract}

JEL Classification: D14, E21.

Keywords: informal credit, local credit markets, inter vivos transfers.

\section{Contents}

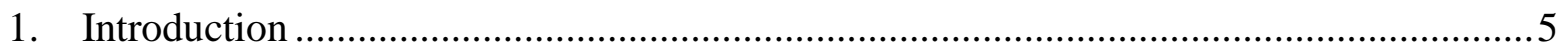

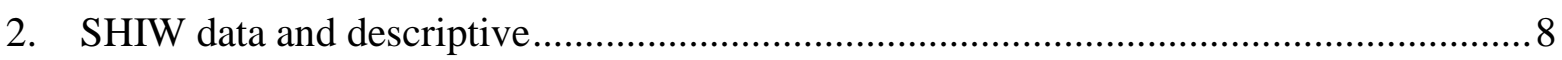

2.1 Informal credit and gifts: definition and features ................................................ 8

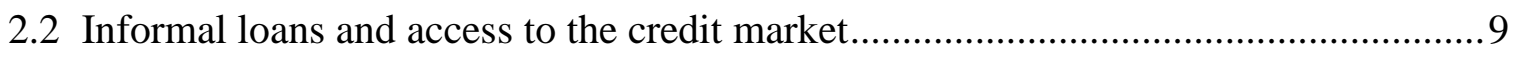

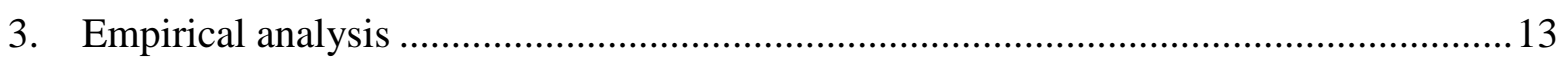

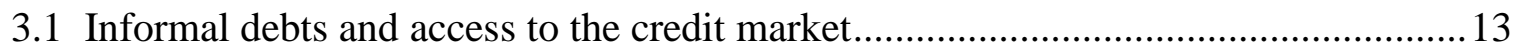

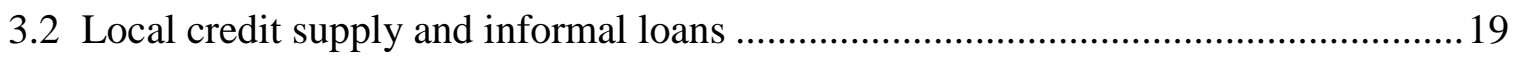

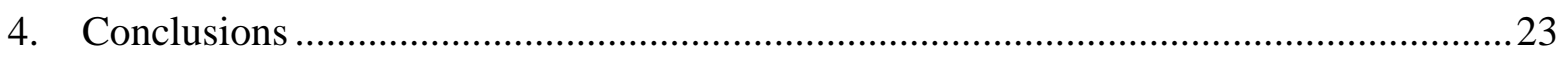

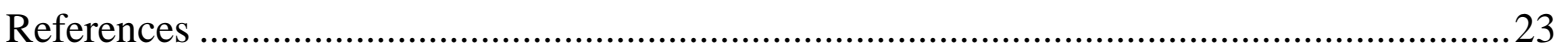

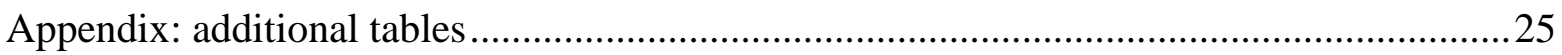

\footnotetext{
* Bank of Italy, Economic Research Unit, Livorno Branch.

** Bank of Italy, Economic Research Unit, Florence Branch.

*** Bank of Italy, Regional Analysis Division, Structural Economic Analysis Directorate.
} 



\section{Introduction ${ }^{1}$}

The study of informal loans (credit from relatives or friends) is a relatively unexplored issue in the context of household financial choices and is only marginally mentioned in recent surveys of the literature on household finance, such as Campbell (2006) and Guiso and Sodini (2012). Nevertheless, this kind of loans are widespread adopted. Informal credit is often used in EU countries (see ECB, 2013); for the United States, the Financial Diaries Project estimates it to be the second most common form of credit, used by two out of every five households.

Two main approaches have been taken in investigating the relationship between formal and informal credit supply, with both approaches converging towards substitutability between the two forms of credit.

The first approach looks at the demand side and mainly relates to low-income countries. It starts from the idea that not every household has access to or is aware of the various sources of credit (see, for example, Campero and Kaiser, 2013). This results in the segmentation of the credit market, where a household's income, education, employment condition, size, and location are capable of affecting its propensity to apply for formal credit.

The second approach looks at the supply side: credit markets, dominated by asymmetric information, are plagued by the phenomena of adverse selection and moral hazard. This results in decreased loan supply and prevents people from borrowing the desired level of money. Such liquidity constraints may impair the life cycle consumption profiles, leading to sub-optimal consumption choices and losses in personal utility.

Either because households are not willing to apply for formal credit or because they are constrained, non-market (informal) arrangements may arise as an endogenous solution to market deficiencies (see Batini et al., 2010, for a review). According to this view, informal transfers would act as a substitute for formal credit: households ask relatives or friends for money when they are not willing or able to access bank credit. As a consequence, a positive relation is expected between being constrained and the occurrence of informal transfers. Indeed, declining liquidity constraints - arising, on the demand side from an increase in income or education level and, on the supply side, from an increase in banking competition or the expansion of bank branch networks should result in a reduction in informal transfers. Furthermore, to the extent credit

\footnotetext{
${ }^{1}$ We thank Laura Bartiloro, Raffaello Bronzini, Conchita D'Ambrosio, Paolo Sestito, and participants at the 3rd "Household Finance and Consumption" workshop (Luxembourg) and at internal seminars at the Bank of Italy for useful comments. The views expressed here are those of the authors and do not necessarily correspond to those of the institutions with which they are affiliated.
} 
rationing behaves anticyclically, so should informal transfers.

An initial theory was provided by Arnott and Stiglitz (1991). Focusing on the insurance market, the authors show that, under certain conditions, peer monitoring by relatives or friends mitigates moral hazard in the formal market. This view is corroborated by the few theoretical and empirical papers investigating this issue. Jain (1999) argues that formal and informal credit markets trade off each other: the former benefits from higher deposit mobilization while the latter exhibits an informational advantage in assessing borrowers' creditworthiness. Empirical applications to the credit market were performed by Cox (1990) and Guiso and Jappelli (1991). The first shows that households with low present and high permanent income (those with a higher probability of being liquidity constrained) are more likely to receive private transfers. The second adopts a model describing the pattern of transfers across generations where the probability of receiving a transfer depends both on whether desired consumption exceeds current consumption and whether liquidity constraints occur. Using the 1987 cross section from the Bank of Italy's Survey on Household Income and Wealth, they find that private transfers are mainly targeted towards liquidity constrained households. The probability of receiving a transfer is 1.7 per cent higher for them, whereas the unconditional probability is 2.7 per cent.

However, looking at the plot of the percentage of Italian households receiving transfers in the period 1995-2014 (Figure 1), we note a mismatch between theoretical predictions and data. During the 1990s and in the first part of the early 2000s, informal loans exhibited a negative trend, ascribed to the development of formal market brought on by an extended deregulation (see Casolaro et al., 2005). We would have expected a continuation of the downward trend during periods of high development of bank lending, with a recovery in the event of a recession. Instead, the data show an unexpected pattern: both before and during the financial crisis the probability of receiving informal credit rose steadily, even in the 2004-2008 subperiod, which saw a large increase in the amount of formal credit to households, principally in the form of long-term loans (Figure 2). ${ }^{2}$ This evidence suggests that a different interpretation of informal credit is warranted, as the standard view about the substitutability between formal and informal credit is not necessarily the most accurate.

In this paper we try to fill the gap by investigating the use of informal credit by households. We exploit data from the Bank of Italy's Survey on Household Income and Wealth (SHIW) in order to shed some light on the existence of different channels of demand with respect to the traditional substitution theory.

\footnotetext{
${ }^{2}$ Households' formal credit rose steadily in the medium- and long-term component between 1995 and 2008 .
} 
Figure 1: Trends in informal loans, monetary gifts and local credit supply, Italy, 19952014

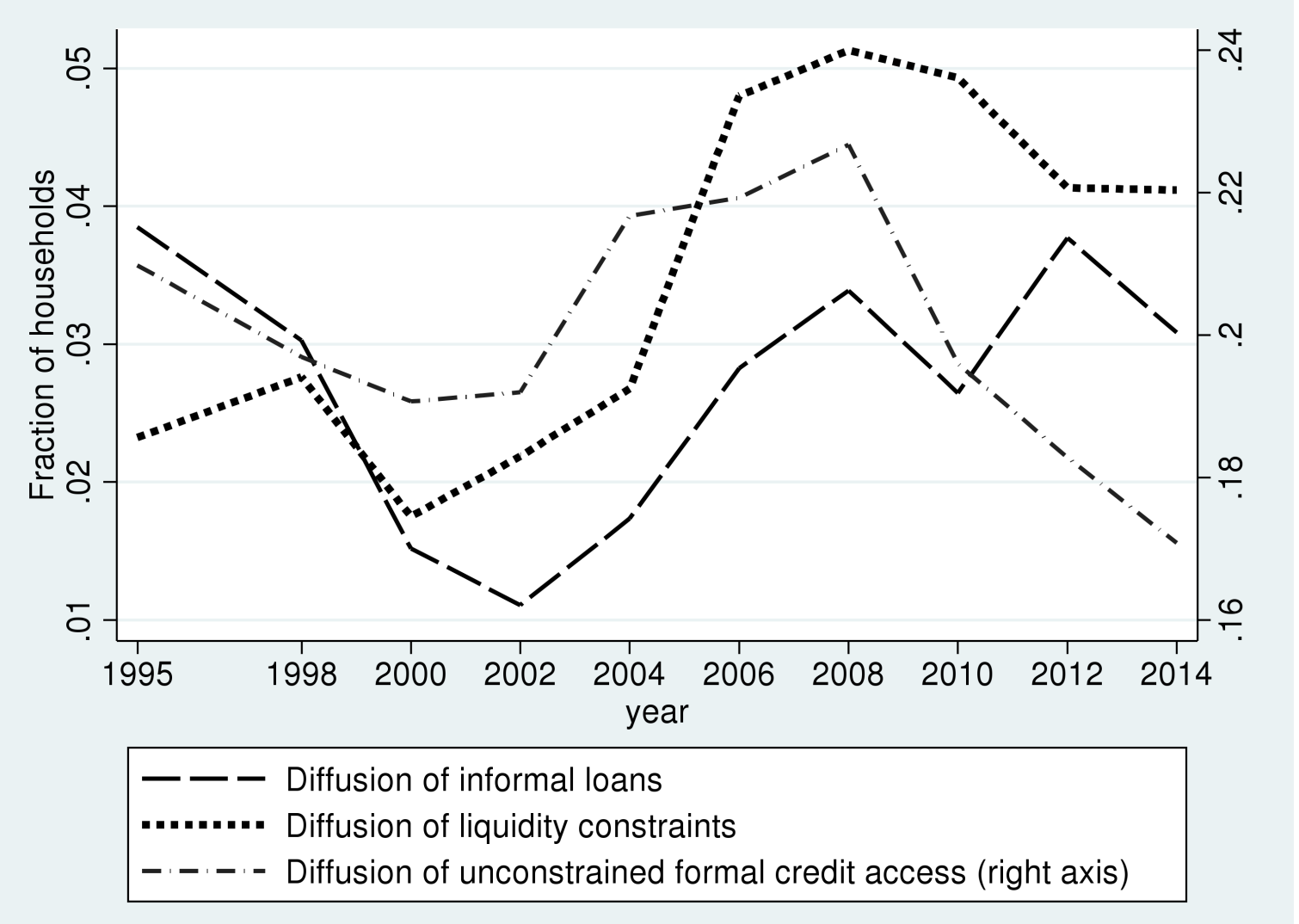

Note: Diffusion is expressed as a fraction of households. Informal loans refer to households who report to being indebted to non-cohabiting relatives or friends at the end of the year. Households are liquidity constrained if they were rejected credit (at least partially) by a bank or if they chose not to apply for a loan thinking that they would have been rejected. Those with unconstrained access to formal credit have formal debt without being liquidity constrained. Sample weights have been used.

The Italian credit market is an interesting setting for the study of informal transfers. First, because of the availability of a high-quality data source, the SHIW, a bi-annual survey of more than 8,000 households with a panel component. Second, the Italian household loan market remained small for a long time by international standards, and it still is, despite a remarkable growth that began in the second half of the 1990s.

Bartiloro and Rampazzi (2015) use SHIW data to study the role of informal credit on consumption during the economic crisis. Unlike them, we exploit the SHIW over an extended period of time in order to provide a more comprehensive framework for informal credit. We move away from the notion that the use of informal transfers is a consequence of failures in the official credit market, showing that this only explains a fraction of informal loans. We find empirical evidence about the existence of a different channel, based on complementarity, where informal credit is used in addition 
Figure 2: Trends in households' formal loans, Italy, 1990-2014, millions of euros.

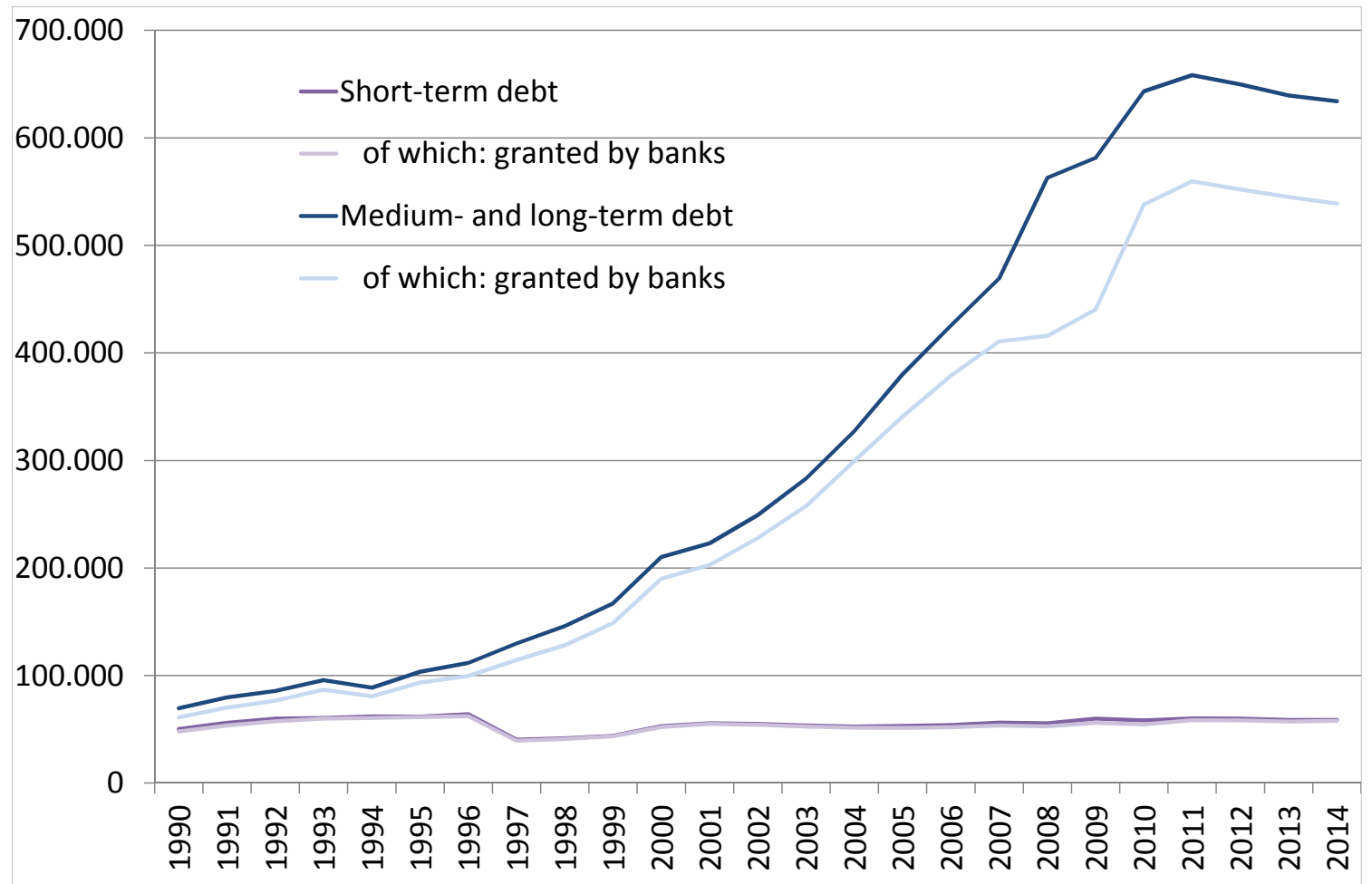

to formal credit or as a backup to avoid default in the event of negative shocks. Finally, we measure the net effect of a change in formal credit supply in local markets.

The paper is organised as follows. Section 2 describes data about informal credit and liquidity constraints in the Italian household credit market. Section 3 reports our empirical analysis on substitution and complementarity channels and their net effect. Section 4 concludes.

\section{SHIW data and descriptive}

\subsection{Informal credit and gifts: definition and features}

SHIW provides detailed information on the economic situation (income, real and financial wealth, indebtedness, savings), consumption and several social characteristics for a stratified sample of over 8,000 households (about 24,000 individuals) from about 300 Italian municipalities. For our purposes, we make use of the period 1995-2014 (10 waves), including a longitudinal component reaching about 50 per cent of the sample. The survey includes a question on informal loans ("At the end of last year did the household have debt with relatives or friends?"). A different question also collects information on gifts ("During the last year did you receive regular gifts or cash from 
relatives or friends?").

Guiso and Jappelli (1991), working on a cross section for 1987, focused their analysis on the probability of receiving a generic transfer, both in the form of an informal loan or as a monetary gift. In the present paper, we mostly focus on informal loans, as we believe that their relation with formal credit may be quite different. Furthermore, the SHIW question on informal loans is related to the stock of debt faced by the households, whenever incurred, while gifts are restricted to those received in the last year.

The regional map of the share of households with informal loans (Figure 3) shows that the densities do not follow the typical North-South divide which characterizes Italy's credit market and major macroeconomic indicators. The incidence of informal credit is higher in the South, as one would expect if banking loans and private transfers are considered substitutes, but there is strong heterogeneity across the regions. Moreover, the average value of transfers in the northern regions is almost double with respect to the southern ones.

Table A2 in the Appendix shows that recourse to informal loans is more frequent for large, low-income families and for households living in large cities. Looking at individual characteristics, the incidence is higher for young, low educated individuals and for divorced people. These features, usually associated with potential difficulties in accessing the credit market, seem to support the traditional hypothesis of informal loans as a substitute for formal loans.

\subsection{Informal loans and access to the credit market}

The SHIW survey contains a specific section dedicated to loan applications and credit rationing. To identify households that are liquidity constrained, the survey asks households who have applied for a loan if they have been turned down, even partially; less than 1 per cent of the sample answered yes, and their share has grown slightly over time, ranging from 0.5 to 1.2 per cent in the period 1998-2014. Each household is also asked: "During the year did you or a member of the household think of applying for a loan or a mortgage to a bank or other financial intermediary, but then changed your mind on the expectation that the application would have been turned down?". Households answering yes to this question, i.e. "discouraged" households, are also potentially credit constrained. Our main dummy for liquidity constrained households therefore includes both cases. This variable has been used extensively in the literature since the seminal paper by Guiso and Jappelli (1991) (see, among others Guiso et al., 2004, 1996). 
Figure 3: Geographical variation in the fraction of households with informal loans

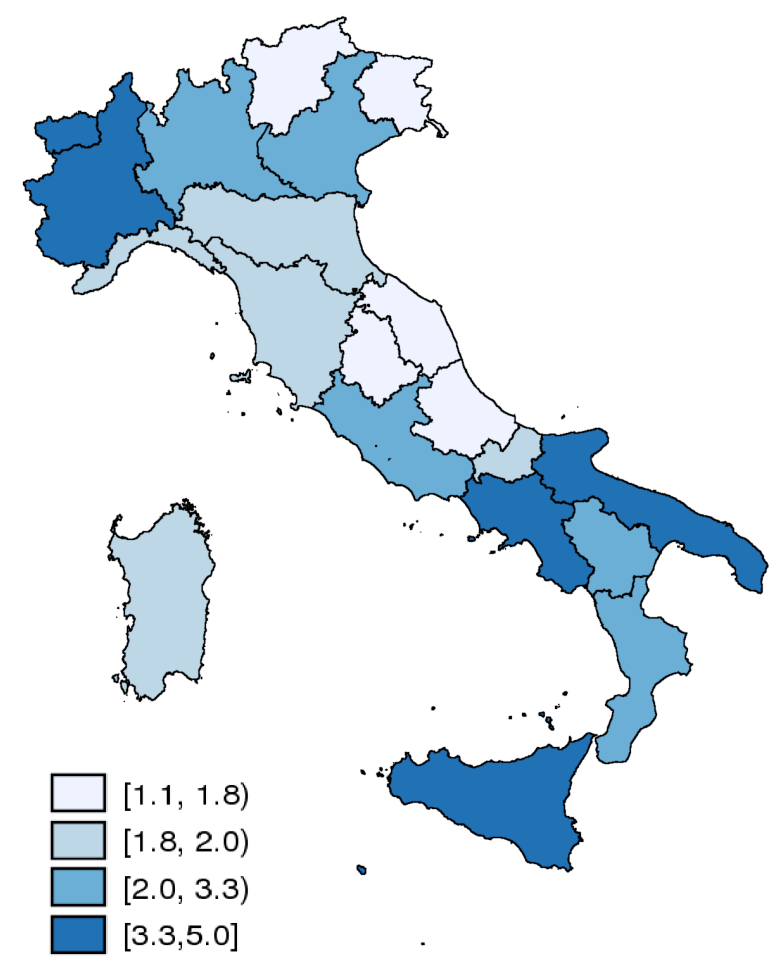

Note: hhs stands for households. The fraction of households (per cent) hasve been calculated based on the pooled 1995-2014 sample. For the definition of informal loans definition, see Figure (1). 
On the other hand, we define households with unconstrained formal credit access as those who either have a loan with a financial institution and did not apply for a new one in the current year, or who applied and obtained the full amount requested. We also exclude discouraged households from this definition. Figure 1 shows that the proportion of households with unconstrained access increased during the period 20042008, reaching its maximum of more than 22 per cent in 2008. Around 78 per cent of households are not liquidity constrained and either do not have loans or have not applied for them.

Figure 4 shows the distribution of households that received an informal loan with respect to their access to the formal credit market. Among households receiving informal loans, more than 50 per cent are not interested in the formal credit market, meaning they neither have loans, nor have they applied for one. Of these, about half do not even hold a bank account. Almost 30 percent of households with informal loans have unconstrained access to the credit market. The remaining 20 per cent faces some problems in accessing the formal market: 6 per cent of households already had a formal loan but were rejected when they applied for a new loan during the last year (or they did not apply because they thought they would have been rejected), while 15 per cent of households were constrained, having no previous access to the credit market. Monetary gifts display similar characteristics, with a higher incidence of households not interested in the credit market. For this group the share rises to about 66 per cent, while it is just 10 per cent for households who have no access to formal credit.

This preliminary evidence suggests that the economics of private loans appears to be more complex than postulated in the literature which considers them as pure substitutes for formal credit. In particular, looking at the data, we believe that private transfers to households could be driven at least by three distinct channels.

The first channel is based on a household version of the pecking order theory (Myers and Majluf, 1984): a certain number of households have a strong preference for a kind of internal liquidity related to transfers from relatives or friends. For this kind of household, informal credit is not an alternative to formal loans but rather is the preferred or even the only option, unaffected by changes in credit market conditions.

The second channel relates to the complementarity between formal and informal credit, recently documented for Chinese firms by Degryse et al. (2013). Many households, far from considering private loans a surrogate for formal credit, use informal financing together with traditional financing. This is also related to the fact that down payments are usually requested, even in advanced financial markets, in order to mitigate adverse selection. Informal credit is often used to meet this requirement. Moreover, the high share of households receiving informal loans with access to the 
Figure 4: Distribution of households with informal loans by credit access, Italy, 19952012

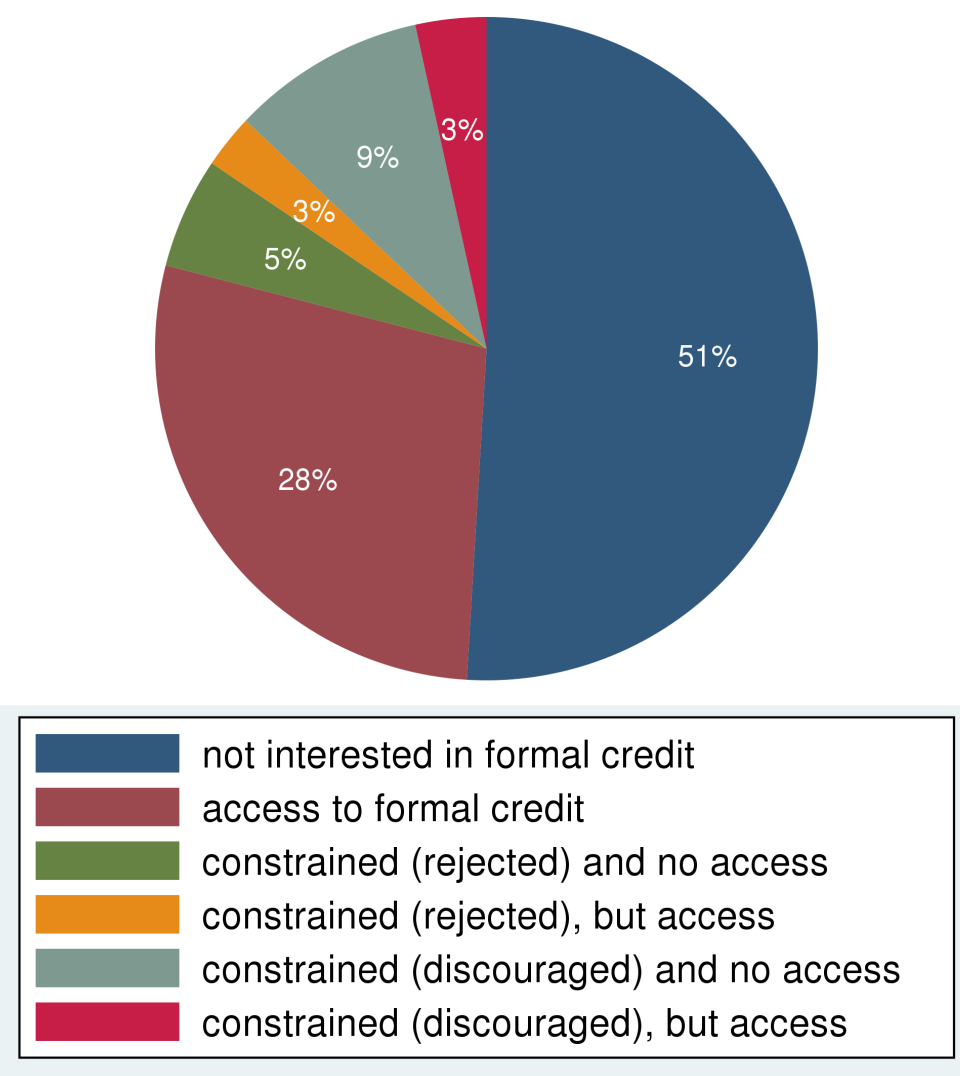

Note: access to formal credit refers to having any kind of formal debt. Liquidity constraint refer to those who report to be rejected at least partially by a bank, and to those who are discouraged (they chose not to apply for a loan thinking that they would have been rejected).

credit market could be linked to a caretaker effect on the part of relatives and friends towards households in financial distress, resulting in delays in loan repayments. In a nutshell, it might be that some households see the two kinds of credit as complementary goods, so that an increase in the availability of formal credit (a reduction in its price) leads to an increase in the demand of informal credit, although in the case of the caretaker effect this may take some time to materialize.

The third channel for informal loans is the one underlined by previous literature (Guiso and Jappelli, 1991), relating to the presence of liquidity constraints. Figure 5 shows the share of households receiving loans and their access to the credit market. Households without any interest in formal financing present a 2 per cent probability of receiving informal loans. The share doubles for households with full access to the credit market. If we focus on constrained households, the percentage with informal loans increases dramatically. On average, it reaches nearly 20 per cent, confirming 
Figure 5: Households with informal loans by access to credit, Italy, 1995-2012

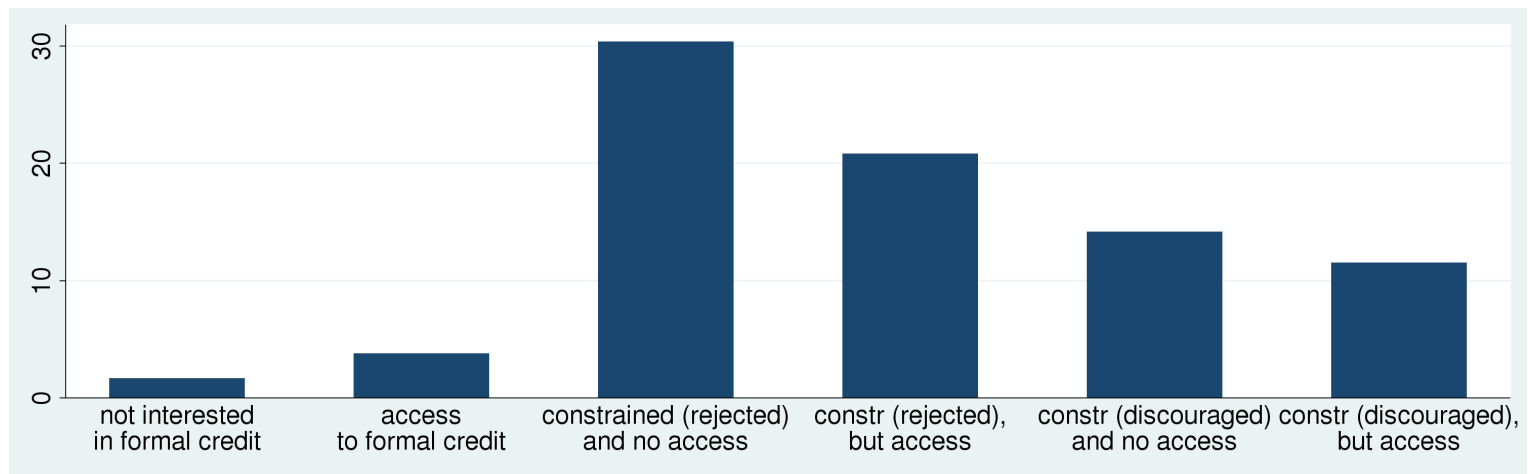

Note: see Figures 1 and 4 for the definitions. The bars represent the percentages of households with informal loans who belong to each group.

that credit rationing is an important channel for informal loan demand. The share increases to 23 per cent for households that requested credit and were turned down, while discouraged households represent about 13 per cent.

\section{Empirical analysis}

\subsection{Informal debts and access to the credit market}

We first start by examining how informal loans are related, at the household level, to their access to the credit market. The dependent variable in our estimations is a dummy equal to one if the household has received informal loans, zero elsewhere. The independent variables, related to the status of households with respect to the credit market, are the presence of credit constraints (rejected and discouraged households are considered both separately and jointly) and the existence of an unconstrained banking relation (both because the household already has a loan or because its application for a new loan has been accepted without rationing). The reference category is represented, therefore, by those households who neither have a formal loan nor have they applied for one.

We control for heterogeneity at the individual level by including covariates describing the head of the household (gender, age, civil status, education, employment status) and the whole household (number of components, number of people getting an income, income net of financial revenues). ${ }^{3}$ We also include geographical controls (at the regional level $r$ ) and temporal dummies for each wave. Summary statistics for

\footnotetext{
${ }^{3}$ These variables also allow us to take into account the position of the specific household inside the life cycle, relevant in influencing borrowing decisions.
} 
these variables are reported in the appendix (Table A3). To summarize, we estimate the following equation:

$$
\begin{aligned}
& y_{i t}=\delta \text { constraint }_{i t}+\gamma \text { formal credit }_{i t}+x_{i t}^{\prime} \beta+\gamma_{t}+\gamma_{r}+\epsilon_{i t} \\
& E\left[\epsilon_{i t} \mid \text { constraint }_{i t}, \text { formal }_{\text {credit }}{ }_{i t}, x_{i t}^{\prime}, \gamma_{t}, \gamma_{r}\right]=0
\end{aligned}
$$

where $i=1, \ldots, N$ are households observed over different years $t=1, \ldots T$ (the panel is unbalanced). This specification is drawn from Guiso and Jappelli (1991), but (i) we focus only on informal loans and not private transfers in general, (ii) we also study the relation with unconstrained access to formal credit, and (iii) we analyze a longer period of time, which also allows us to introduce household fixed effects.

Table 1, column (1), shows the results of our principal estimation, an OLS regression for the period 1995-2014 over a pooled sample of more than 70 thousand observations. The empirical analysis confirms the results found in the existing literature: credit-constrained households are 13 per cent more likely to receive informal loans than the rest of the sample. However, when compared with those who are not interested in the credit market (they do not have formal loans and have neither applied nor wanted to apply for them), even households with unconstrained access to the credit market are more likely to receive informal loans, corroborating our hypothesis about the presence of a complementary channel. The estimated coefficients for control variables have the expected signs: the probability of receiving transfers is higher for larger families and for divorced couples; it decreases with household income and the age of the head of household (coefficients available on request).

The results are robust to alternative specifications. We performed a logit estimation (column 2) and the results are completely in line with the previous ones, even in the magnitude of the marginal effects.

One possible concern is that there are household-specific cultural traits that make individuals less inclined to ask for formal credit and more prone to rely on relatives and friends. The sign of the bias is potentially unclear. Those who are skeptic towards formal credit are more likely to be among those who are liquidity constrained, in particular the discouraged, but also those who neither have a formal loan nor have applied for one. To address this issue we exploit the panel dimension of the dataset and run a fixed effect estimation. Since we expect these cultural traits to persist over time, the household fixed effects should capture most of this omitted variable bias. In FE estimates (column 3) the qualitative conclusions are confirmed, even if the coefficients on the dummies of interest are smaller: we still find that being liquidity constrained has a large effect and that there is a positive relation with unconstrained access to 


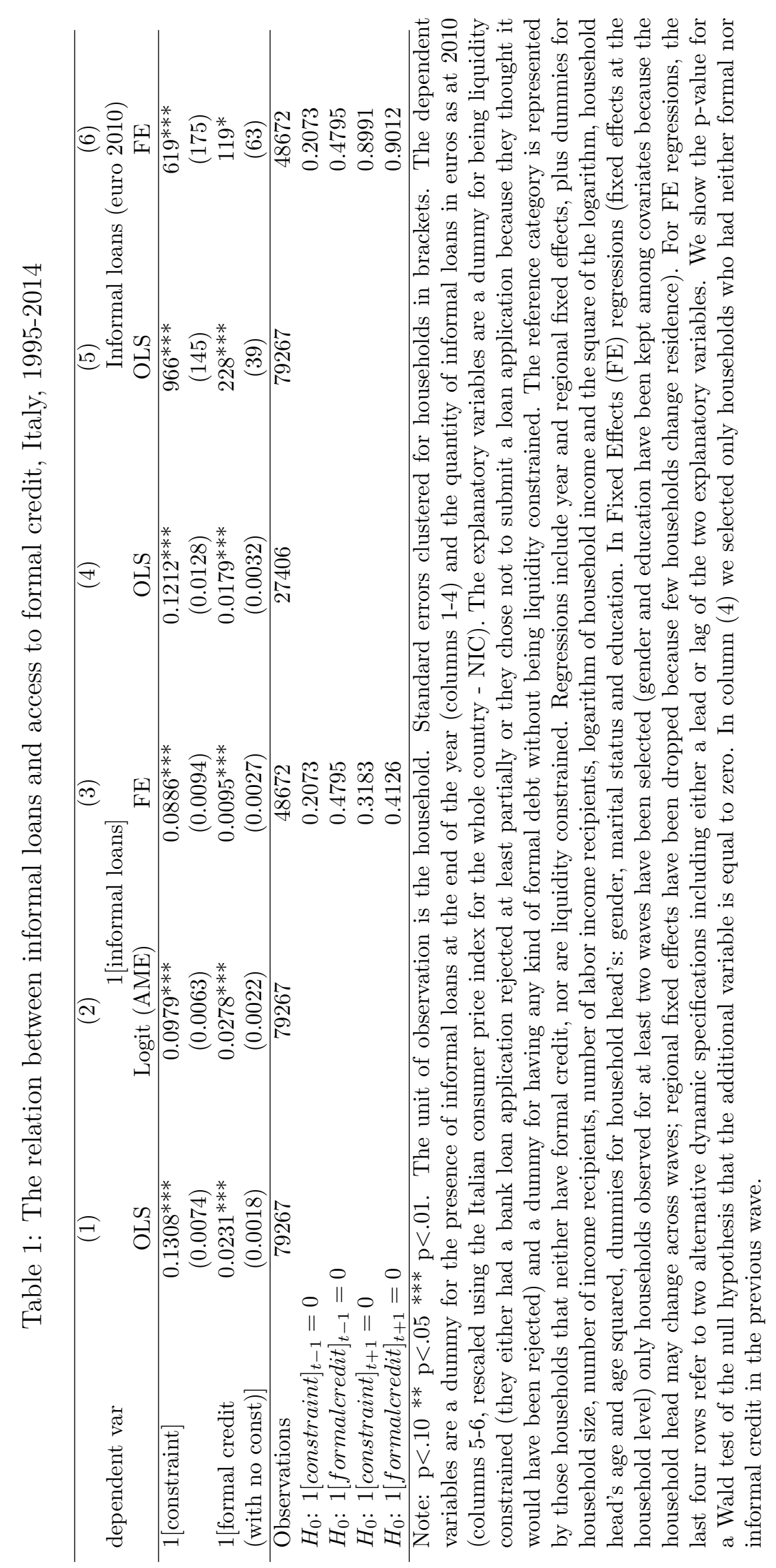


formal credit. As a robustness check we tried adding lags or leads of the liquidity constraint dummies to the FE estimates, but they are not statistically significant at the $5 \%$ level. Finally, we replaced regional dummies with provincial dummies in the specification from column (1) and the results are virtually unchanged.

To confirm the presence of a non-negligible complementarity channel, in column (4) of Table 1 we focus on the longitudinal sample. We check whether households with neither formal nor informal loans in one wave are more likely, in the following wave, to borrow from relatives or friends if they request and obtain a (formal) loan. Results are indeed very similar to the main ones. ${ }^{4}$ With respect to the sample averages in the selected sample (2.6 per cent for informal loans), unconstrained access to the credit market is associated with an increase of more than 66 per cent in the share of households indebted to relatives or friends.

In the main results we focused on the extensive margin, that is, on the probability of receiving credit from relatives or friends. Exploiting information about the amount of credit, we can also check for the effects of credit rationing on the size of the informal loan, conditioning on the attainment of such a transfer. We therefore run the same regressions using the quantity of informal credit as the dependent variable (columns 5-6). Estimates confirm our previous conclusions.

Finally, results may be different for some socio-economic groups. Young and poorer individuals may have stronger needs for credit and at the same time are more likely to be liquidity constrained. There may also be significant geographical differences due to different attitudes toward formal credit and to the degree of familism, which is higher in the South. Table 2 shows that results are very similar between young and old households. Although the former are more likely to be liquidity constrained, the relation with informal loans is similar. Geographical heterogeneity is instead quite large for the coefficient on the constraint dummy, while it is negligible in the other variables. Those households with higher per-capita income are less likely to use informal loans in any case, as we intuitively expected. Overall, although some noticeable differences arise, in particular for the constraint dummy, qualitative conclusions are quite similar in all groups.

Complementarity may be stronger when households indebted to a financial institution have problems paying back their mortgage. We perform an estimation on a subsample of households who (i) hold a formal loan both in the current and previous wave, (ii) were not informally indebted and did not they receive a gift in the previous

\footnotetext{
${ }^{4}$ It would be interesting to understand whether complementarity also depends on the purpose of the formal loan. Unfortunately, direct information is fully available only for 2012, which is not sufficient to run the regressions (in 2010 only those who were rejected were asked).
} 
Table 2: Heterogeneity in the relation between informal loans and access to formal credit, Italy, 1995-2014

\begin{tabular}{|c|c|c|c|c|c|c|}
\hline \multirow{3}{*}{$\begin{array}{l}\text { Dependent var: } \\
\text { Subsample: }\end{array}$} & \multirow{2}{*}{\multicolumn{6}{|c|}{ 1[informal loans] }} \\
\hline & & & & & & \\
\hline & $\begin{array}{c}\text { Young } \\
\text { house- } \\
\text { holds }\end{array}$ & $\begin{array}{c}\text { Older } \\
\text { house- } \\
\text { holds }\end{array}$ & $\begin{array}{l}\text { Centre } \\
\text { North }\end{array}$ & South & $\begin{array}{l}\text { Per-capita } \\
\text { income } \\
\text { less than } \\
\text { the } \\
\text { median }\end{array}$ & $\begin{array}{l}\text { Per-capita } \\
\text { income } \\
\text { above the } \\
\text { median }\end{array}$ \\
\hline 1 [constraint] & $\begin{array}{c}0.1140^{* * *} \\
(0.0170)\end{array}$ & $\begin{array}{c}0.1340^{* * *} \\
(0.0082)\end{array}$ & $\begin{array}{c}0.1050^{* * *} \\
(0.0084)\end{array}$ & $\begin{array}{c}0.1743^{* * *} \\
(0.0139)\end{array}$ & $\begin{array}{c}0.1557^{* * *} \\
(0.0099)\end{array}$ & $\begin{array}{c}0.0840^{* * *} \\
(0.0103)\end{array}$ \\
\hline $\begin{array}{l}1 \text { [formal credit } \\
\text { (with no const)] }\end{array}$ & $\begin{array}{c}0.0270^{* * * *} \\
(0.0050)\end{array}$ & $\begin{array}{c}0.0219^{* * * *} \\
(0.0019)\end{array}$ & $\begin{array}{c}0.0220^{* * *} \\
(0.0020)\end{array}$ & $\begin{array}{c}0.0244^{* * *} \\
(0.0035)\end{array}$ & $\begin{array}{c}0.0307^{* * * *} \\
(0.0029)\end{array}$ & $\begin{array}{c}0.0162^{* * * *} \\
(0.0020)\end{array}$ \\
\hline Observations & 9394 & 69873 & 52090 & 27177 & 39623 & 39644 \\
\hline
\end{tabular}

wave, and presented no delays in payments in the previous wave. ${ }^{5}$ The equation we estimate is ${ }^{6}$

$$
\begin{gathered}
y_{i t}=\gamma \text { repayment delay }_{i t}+x_{i t}^{\prime} \beta+\gamma_{t}+\gamma_{r}+\omega_{i t} \\
E\left[\omega_{i t} \mid \text { repayment delay }_{i t}, x_{i t}^{\prime}, \gamma_{t}, \gamma_{r}\right]=0
\end{gathered}
$$

The results presented in Table 3, column (1) show that the emergence of financial distress for households with formal loans (signaled by a delay in payments) increases the probability of receiving an informal loan by 16 per cent. This finding indicates that at least part of the observed complementarity is driven by a backup effect generated by relatives and friends with respect to households with financial problems. The analysis leads to a strong drop in the number of observations, due to both the small fraction of households with debt and the fact that the question about payment delays entered the survey in 2008, so the sample for the estimation (households having no delays in the past wave) only includes the waves from 2010 to 2014 . We test the robustness of the results by relaxing the assumption of not having delays at time t-1 for households with loans. In this way we are able to include one more wave and increase the size of

\footnotetext{
${ }^{5}$ Also Bartiloro and Rampazzi (2015), analyzing the correlates of informal credit, note that those who are late in paying back their debts are more likely to have informal credit. However, in their estimates they do not exploit the longitudinal dimension, making it more difficult to interpret the positive correlation as a caretaker effect.

${ }^{6}$ We do not include a control for liquidity constraints, given that these households are already indebted in the credit market. Results are basically unchanged if we add the relative dummy among the regressors.
} 
Table 3: Delay in debt-repayment and informal credit

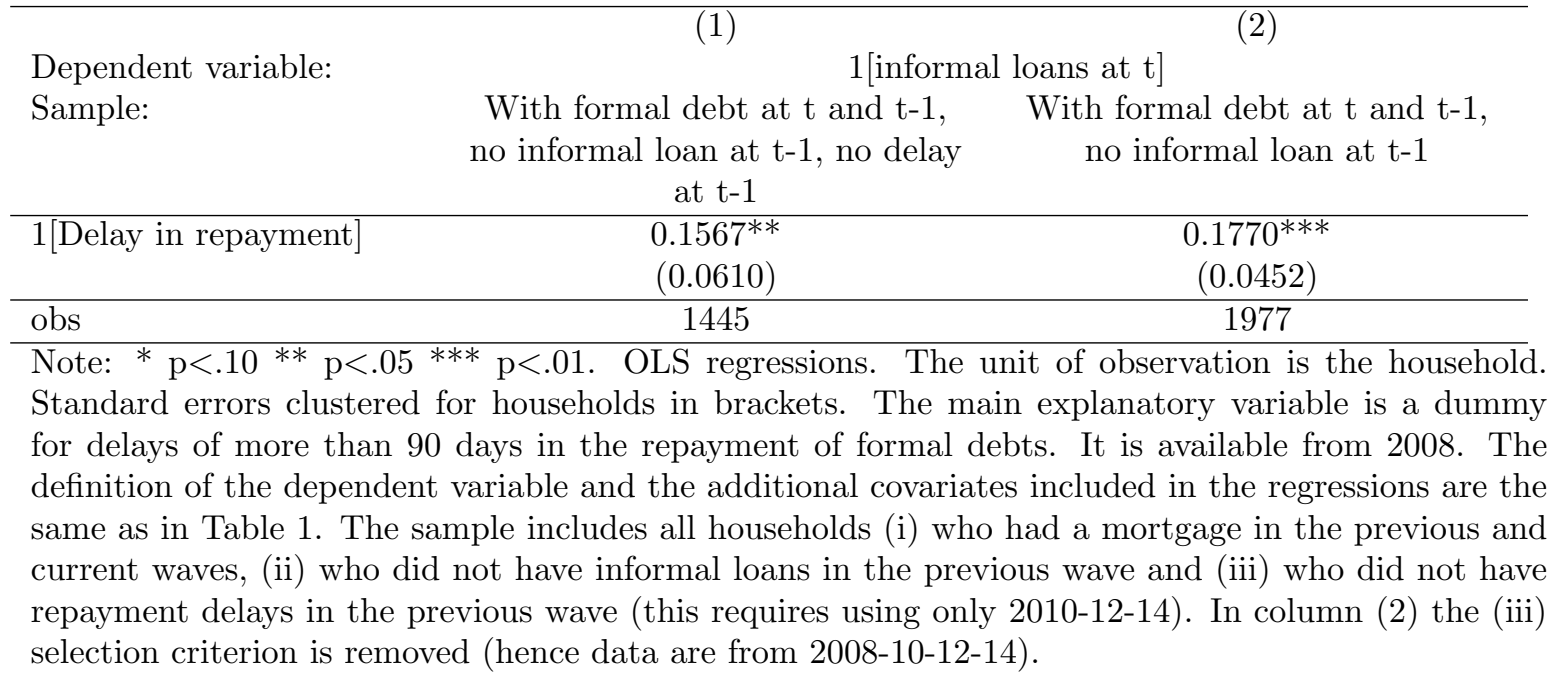

Table 4: Monetary gifts and access to formal credit, Italy, 1995-2014

\begin{tabular}{lccc}
\hline Dependent var: & $(1)$ & $\begin{array}{c}(2) \\
1[\text { monetary gifts] } \\
\text { Logit (AME) }\end{array}$ & FE \\
\hline 1 constraint] & OLS & $0.0975^{* * *}$ & $0.0885^{* * *}$ \\
& $0.1306^{* * *}$ & $(0.0063)$ & $(0.0094)$ \\
1 formal credit (with no const)] & $0.0227^{* * *}$ & $0.0279^{* * *}$ & $0.0097^{* * *}$ \\
& $(0.0018)$ & $(0.0022)$ & $(0.0027)$ \\
\hline Observations & 79267 & 79267 & 48672 \\
Equality constraint for the coefficient in gift regressions vs informal loans (p-value): & 0.000 \\
1 constraint] & 0.000 & 0.000 & 0.811 \\
1 formal credit (with no const)] & 0.000 & 0.000 & .
\end{tabular}

Note: $\mathrm{p}<.10^{* *} \mathrm{p}<.05^{* * *} \mathrm{p}<.01$. The unit of observation is the household. Standard errors clustered for households in brackets. The dependent variable is a dummy for the receipt of gifts from relatives or friends. The last two rows refer to a test for the difference of the coefficients from the equations on informal loans. The definition of the dependent variable and the additional covariates included in the regressions are the same as in Table 1.

the sample by 30 per cent. Results (column 2) are nevertheless quite similar.

Although our main focus is on informal loans, households may receive private transfers in the form of gifts. Table 4 shows that the relation between formal credit and gifts has similar characteristics to the relation between formal and informal loans, but the magnitude of the coefficient is generally smaller, apart from the case of the coefficient on unconstrained access to formal credit in FE regressions. We also checked the regressions with the monetary amount of gifts as a dependent variable (both OLS and FE), and the coefficients on the two dummies of interest were smaller than 30 (euros) and not statistically significant. 


\subsection{Local credit supply and informal loans}

Thus far we have shown that two different channels simultaneously influence the probability of receiving an informal loan. These channels act inversely with respect to formal credit dynamics: on the one side informal support is needed when formal credit is not available (or is believed to be unavailable); on the other side obtaining formal credit may actually foster informal credit. Indeed, analysing which one prevails may prove worthy in understanding the phenomenon and may provide useful insights with implications for policy. For this reason, as a final step, we try to measure the net effect on informal loans of the credit market dynamics at the local level.

In order to do so, we use data from the Bank of Italy's Supervisory Reports and Central Credit Register on the amount and quality of bank loans in local credit markets. These series are available from 1998, and therefore we exclude 1995 from this analysis. ${ }^{7}$ In the baseline regression of this Section we exploit the panel dimension of our database estimating, at the provincial level, the impact of the flow of new formal loans per capita granted to households on the probability of increasing the usage of informal credit. However, in order to understand whether the two kinds of credit are on average complements or substitutes, we need to exploit changes in the amount of bank loans that are due to shocks to the supply of formal credit. In other words, we want to estimate whether an increase in the supply of bank loans leads to an increase or a decrease in the consumption of informal credit.

To this aim we introduce an instrument for credit supply obtained by exploiting the huge heterogeneity in non-performing loans to firms observed in the period of interest and in particular during the crisis. In 1998, focusing on credit to firms, the incidence of bad loans was 10 per cent; the value decreased until 2006 (8 per cent), then increased during the crisis, reaching 20 per cent in 2014. We obtain local indexes of the quality of firm credit by computing the fraction of non-performing loans over total loans for each bank and year at national level, and then projecting them in the local setting on the basis of the banks' market share in each province. We define this variable credit-quality . $_{\text {. }}$

The instrument is supposed to have a strong negative correlation with new loans granted to households, given that the emergence of bad loans, which decrease bank profitability and commit a larger amount of their capital, affects the propensity of banks to grant new credit. On the other hand, we also claim that, after controlling for household covariates and regional peculiarities, the quality of firm credit does not

\footnotetext{
${ }^{7}$ Data for the first quarter of 1998, not available in the Central Credit Register dataset, have been retroactively extrapolated by applying, at provincial level, the average growth rate of the last three quarters of the same year.
} 
have a direct impact on informal loans to households, neither through its demand nor its supply. This assumption seems reasonable given that the dynamics of bad loans to firms is affected by variables that are different with respect to households (Bofondi and Ropele, 2011) and tend to occur over a different temporal pattern. Moreover, the way we construct our provincial indexes allows us to distribute local credit shocks on the basis of a bank's market share, thus weakening the correlation between the quality of loans to firms in the local market and household credit supply.

To summarize, we estimate the equation:

$$
\Delta y_{i g t}=\delta \text { credit-flow }_{g t}+\Delta x_{i t}^{\prime} \beta+\gamma_{t}+\gamma_{r}+\eta_{i g t}
$$

where the variable $\Delta y_{i g t}$ describes a household's changes in its informal credit status: it is equal to 0 if there is no change in status, equal to 1 if a household without an informal loan at time $t$ obtains a loan from relatives or friends in the following period, while it is equal to -1 in the opposite case. ${ }^{8}$ Even if we have to exclude the 1995 wave from the analysis, we still use it to calculate the changes for 1998. The variable credit - flow represents the flow of new loans to households per capita, while $g=1, \ldots, G$ stands for provinces. Although our regression is in first-differences, we still include regional dummies in order to capture differential linear trends across regions. ${ }^{9}$

Our empirical strategy is the following. We initially run OLS, assuming that the variation in bank loans is entirely due to changes in the supply of formal credit:

$$
E\left[\eta_{i g t} \mid \text { credit-flow }_{g t}, \Delta x_{i t}^{\prime}, \gamma_{t}, \gamma_{r}\right]=0
$$

However, credit-flow $g$ is likely to be correlated with the unobserved component $\eta_{\text {igt }}$, both because formal and informal credit are likely to be jointly determined, and because of possible omitted variables. ${ }^{10}$ We therefore move on to a different identification strategy, allowing for this correlation to be different from zero, but assuming that the quality of loans to firms represents a source of variation in the supply of formal credit which has no direct impact on informal loans:

$$
\operatorname{Cov}\left[\eta_{\text {igt }}, \text { credit-quality }{ }_{g t}\right]=0 .
$$

\footnotetext{
${ }^{8}$ We observe 648 positive changes and 703 negative ones.

${ }^{9}$ The variability of the credit-flow and of the instrument is not only at the provincial level, but also over time. However, in the specification we included only regional dummies, because the dependent variable has a limited variability within provinces over time. Nevertheless, estimates for the effect of interest are confirmed to be positive and significant, even if somewhat larger, when we also include provincial fixed effects.

${ }^{10}$ In particular, we expect the area with the best economic performances to present the most developed credit market.
} 
Assuming this absence of correlation (exclusion restriction), we can estimate equation (5) by 2SLS, using credit-quality ga $_{\text {a }}$ an instrument for credit-flow . $_{\text {. }}$

The results of the estimation, performed for the period 1998-2014 on the households belonging to the panel, are reported in Table 5. The OLS regression presented in the first column highlights a small, positive relation between the supply of new loans to households and the use of informal loans. An increase of 10 per cent in new loans to households in a province is associated with an increase in the probability of receiving an informal loan in the order of 0.1 percentage points. This result can be explained by a larger role played by the complementary effect on formal credit with respect to the substitution effect due to credit rationing. Also, our estimates may capture only part of the complementarity, because the caretaker effect discussed above is likely to materialize with some lag.

Table 5: Informal loans and local bank credit supply, Italy, 1998-2014

\begin{tabular}{|c|c|c|c|}
\hline Dependent var: & $\begin{array}{c}(1) \\
\Delta 1[\text { informalloans }]_{t}\end{array}$ & $\begin{array}{c}(2) \\
1[\text { informalloans }]_{t}\end{array}$ & $\begin{array}{c}(3) \\
\Delta 1[\text { informalloans }]_{t}\end{array}$ \\
\hline & OLS & OLS & 2 SLS \\
\hline & $0.0102^{* *}$ & & 0.020 \\
\hline & & & \\
\hline & & & \\
\hline Obs & 35721 & 71150 & 35721 \\
\hline First-stage F & & & 52.2 \\
\hline \multicolumn{4}{|c|}{$\begin{array}{l}\text { Note: }{ }^{*} \mathrm{p}<.10^{* *} \mathrm{p}<.05^{* * *} \mathrm{p}<.01 \text {. The unit of observation is the household. Standard errors } \\
\text { clustered for province }(\mathrm{G}=95) \text { in brackets. See Table } 1 \text { for the definition of informal loans. Formal } \\
\text { bank credit per capita is the total amount provided to households at the provincial level divided by } \\
\text { total population. All regressions include annual and regional fixed effects. The regressions also control } \\
\text { for a set of variables } x_{i t} \text { that includes dummies for household size, number of income recipients, number } \\
\text { of labor income recipients, logarithm of household income and the square of the logarithm, household } \\
\text { head's age and age squared, dummies for household head's: gender, marital status and education. In } \\
\text { columns (1) and (3) these variables } x_{i t} \text { are in first difference (household head's gender and education } \\
\text { are included, as the household head may change, but excluding them makes no difference). In the } \\
\text { last column the instrument is the predicted ratio of deteriorated bank loans to firms at the provincial } \\
\text { level (see text for more details); the first stage coefficient is -3.654 (s.e. .506). }\end{array}$} \\
\hline
\end{tabular}

As a robustness check, we perform an estimation using, as dependent variable, a dummy equal to one for households with informal loans and, as a proxy of credit supply, the stock of loans to households per capita at provincial level. The results, shown in the second column, are qualitatively unchanged, but larger.

In order to control for endogeneity and recover the actual effect of a shift in formal credit supply, we finally perform a two- stage estimation using the instrumental variable discussed before. The first stage, not shown in the tables, confirms our expectations. An increase by one percentage point in the predicted rate of deteriorated loans in the firm sector leads to a contraction in the flow of per-capita new formal credit 
to households by 3.7 percent. The effect on informal loans, estimated by 2SLS and displayed in the third column, remains significant and positive. We observe a large increase in magnitude with respect to OLS, but it remains quite small from an economic perspective.

One concern about our instrument is that it may violate the exclusion restriction for those households whose main source of income is from their own firms or selfemployment, because in this case there may be a more direct link between the quality of loans in the firm sector with household demand for informal loans. We checked and the 2SLS estimate is quite similar if we exclude households whose main earner is self-employed or an entrepreneur (column 1 of Table 6), or if we focus only on those who are blue- or white-collar workers (column 2).

Table 6: Informal loans and local bank credit supply, Italy, 1998-2014, robustness checks for the 2SLS estimate

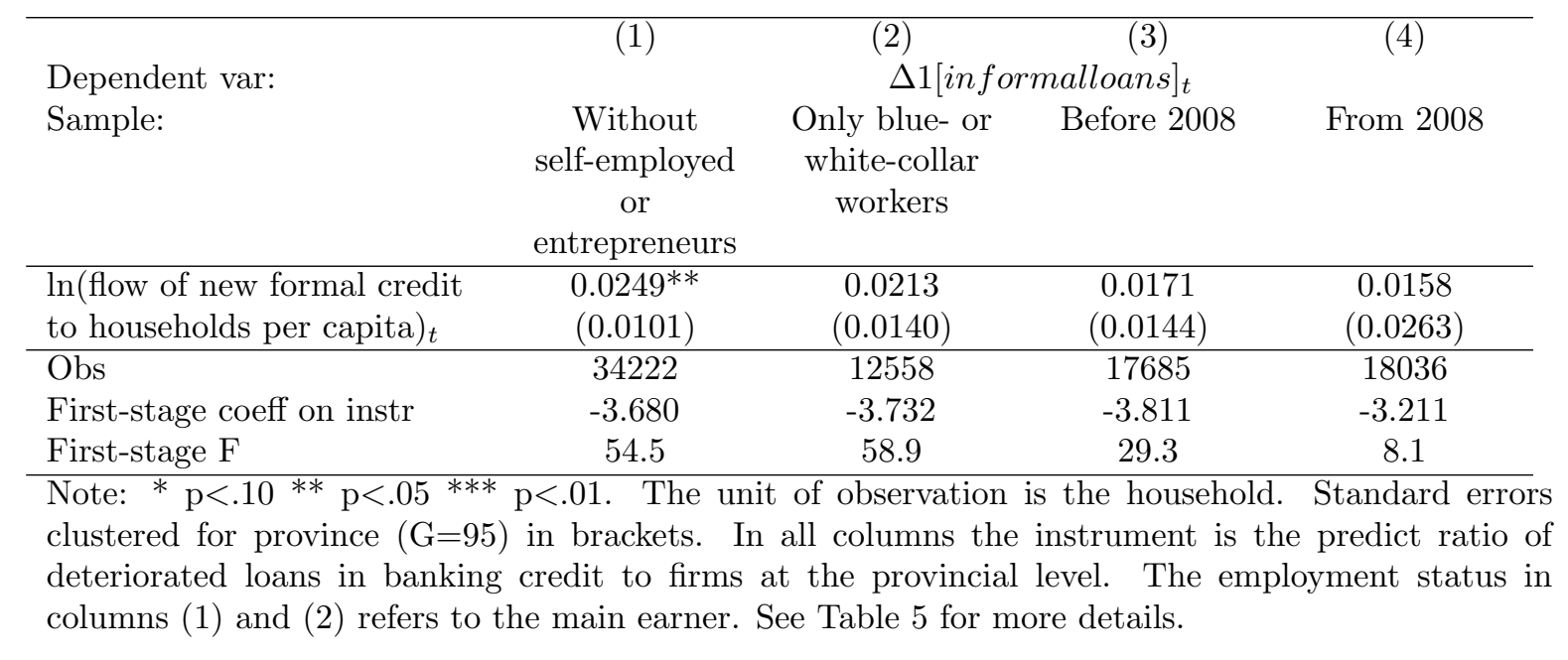

Another possible issue is that during the crisis, when deteriorated firm loans expanded, household expectations became more pessimistic, leading to a contraction in the demand for non-durables and possibly in the demand for informal loans. Although we are controlling for changes in income and occupational status of the household head, this may still lead to an upward bias in our estimates. Columns (3) and (4) split the sample between the two periods. The first stage, despite showing similar coefficients, becomes weaker after 2008, which is partially due to decreased sample size, but also suggests that part of the identification comes from the variation occurring with the crisis. The 2SLS estimates become weaker and less significant. Nevertheless, they are not far in magnitude from the main results and confirm the positive, but small, impact on informal loans. 


\section{Conclusions}

We tried to shed some light on the economics of informal credit used by households. The view of the mainstream literature is based on the general idea that informal markets take place when the functioning of formal ones is impaired. This way, as far as households are concerned, the diffusion of informal loans has been considered a proxy for credit market inefficiency: the larger, the more policy action is needed.

We enlarge this view using data over a relatively long period of time. As a first step we show that, indeed, this mechanism is at work, so that the probability of receiving an informal loan grows with the magnitude of credit rationing. However, we highlight the presence of a second channel, related to the complementarity between access to the formal credit market and demand for informal loans. As a result, the net effect is a priori unclear. Focusing on the local supply of formal banking credit, we show that the complementarity channel seems to prevail in our data, even if the overall impact on informal loans is rather limited.

This result has two important policy implications. First of all, the development of financial institutions does not necessarily lead to the disappearance of the informal market. Secondly, the presence of informal loans, usually considered an index of financial backwardness, may represent an important complement to the diffusion of formal credit and a valid support in the case of financial distress.

\section{References}

Arnott, R. and J. E. Stiglitz (1991). Moral Hazard and Nonmarket Institutions: Dysfunctional Crowding Out of Peer Monitoring? The American Economic Review 81 (1), 179-190.

Bartiloro, L. and C. Rampazzi (2015). Il sostegno finanziario della rete familiare durante la crisi. Bank of Italy Occasional Paper 291.

Batini, N., Y.-B. Kim, P. Levine, and E. Lotti (2010). Informal labour and credit markets: a survey. International Monetary Fund Working Paper, 1-42.

Bofondi, M. and T. Ropele (2011). Macroeconomic determinants of bad loans: evidence from Italian bank. Bank of Italy Occasional Paper (89).

Campbell, J. Y. (2006). Household finance. Journal of Finance 61(4), 1553-1603.

Campero, A. and K. Kaiser (2013). Access to Credit: Awareness and Use of Formal and Informal Credit Institutions. Banco de Mexico Working Paper 7, 1-33. 
Casolaro, L., L. Gambacorta, and L. Guiso (2005). Regulation, formal and informal enforcement and the development of the household loan market. Lessons from Italy. Bank of Italy Working Paper (560), 1-60.

Cox, D. (1990). "Intergenerational Transfers and Liquidity Constraints. Quarterly Journal of Economics (105), 187-217.

Degryse, H., L. Lu, and S. Ongena (2013). Informal or Formal Financing? Or Both? First Evidence on the Co-Funding of Chinese Firms. CEPR Discussion Papers (9519), 1-61.

ECB (2013). The Eurosystem Household Finance and Consumption Survey. Results from the first wave. Statistics Paper Series (2).

Guiso, L. and T. Jappelli (1991). Intergenerational transfers and capital market imperfections. European Economic Review 35, 103-120.

Guiso, L., T. Jappelli, and D. Terlizzese (1996). Income Risk, Borrowing Constraints, and Portfolio Choice. The American Economic Review 86(1), 158-172.

Guiso, L., P. Sapienza, and L. Zingales (2004). Does local financial development matter? Quarterly Journal of Economics, 929-969.

Guiso, L. and P. Sodini (2012). Household finance. An emerging field. EIEF Working Paper (04/12), 1-213.

Jain, S. (1999). Symbiosis vs. crowding-out: the interaction of formal and informal credit markets in developing countries. Journal of Development Economics 59, 419444.

Myers, S. and N. Majluf (1984). Corporate financing and investment decisions when firms have information that investors do not have. Journal of Financial Economics (13), 187-221. 


\section{Appendix: additional tables}

Table A1: Summary statistics

\begin{tabular}{|c|c|c|c|c|c|c|c|c|c|c|}
\hline & 1995 & 1998 & 2000 & 2002 & 2004 & 2006 & 2008 & 2010 & 2012 & 2014 \\
\hline & \multicolumn{10}{|c|}{ Informal loans } \\
\hline no. & 299 & 242 & 102 & 85 & 137 & 185 & 257 & 227 & 286 & 237 \\
\hline ratio (percent) & 3.7 & 3.4 & 1.3 & 1.1 & 1.7 & 2.4 & 3.2 & 2.9 & 3.5 & 2.9 \\
\hline mean & 9,436 & 8,127 & 9,923 & 11,742 & 8,506 & 7,275 & 6,312 & 8,121 & 7,367 & 7,654 \\
\hline 1st quarter & 2,166 & 1,335 & 1,920 & 2,354 & 1,682 & 1,616 & 1,535 & 1,500 & 1,889 & 1,862 \\
\hline median & 4,332 & 3,336 & 4,481 & 5,884 & 3,363 & 3,231 & 3,070 & 3,000 & 3,777 & 3,724 \\
\hline 3rd quarter & 10,830 & 8,007 & 12,802 & 11,768 & 5,605 & 5,385 & 5,117 & 6,500 & 7,554 & 7,449 \\
\hline
\end{tabular}


Table A2: Share of households with informal loans (percent)

\begin{tabular}{|c|c|c|}
\hline & Fraction of households in each category & Distribution across categories \\
\hline \multicolumn{3}{|c|}{ Area } \\
\hline North West & 2.8 & 25.5 \\
\hline North East & 1.9 & 14.9 \\
\hline Centre & 1.6 & 12.4 \\
\hline South & 4.0 & 34.0 \\
\hline Islands & 3.1 & 13.2 \\
\hline \multicolumn{3}{|c|}{ Gender } \\
\hline Men & 2.6 & 68.9 \\
\hline Women & 2.7 & 31.1 \\
\hline \multicolumn{3}{|c|}{ Age } \\
\hline Under 30 & 4.9 & 10.4 \\
\hline $31-40$ & 4.4 & 23.0 \\
\hline $41-50$ & 4.0 & 29.5 \\
\hline $51-65$ & 2.2 & 23.7 \\
\hline Over 65 & 1.1 & 13.4 \\
\hline \multicolumn{3}{|c|}{ Marital status } \\
\hline Married & 2.6 & 61.5 \\
\hline Single & 2.8 & 17.0 \\
\hline Separated/divorced & 4.4 & 10.7 \\
\hline Widowed & 1.8 & 10.8 \\
\hline \multicolumn{3}{|c|}{ Education } \\
\hline None or elementary school & 2.3 & 26.7 \\
\hline Middle school & 3.7 & 42.0 \\
\hline High school & 2.3 & 24.2 \\
\hline University degree or higher & 1.8 & 7.0 \\
\hline \multicolumn{3}{|c|}{ Work status } \\
\hline Blue-collar worker & 4.4 & 32.0 \\
\hline Office worker, teacher & 2.3 & 15.0 \\
\hline Junior manager & 1.7 & 2.1 \\
\hline Senior manager & 1.2 & 0.7 \\
\hline Freelance & 2.2 & 2.2 \\
\hline Entrepreneur & 2.9 & 10.2 \\
\hline Not employed & 2.2 & 37.8 \\
\hline \multicolumn{3}{|c|}{ Town size } \\
\hline Under 20,000 & 2.2 & 22.4 \\
\hline $20,000-40,000$ & 2.1 & 15.3 \\
\hline $40,000-500,000$ & 3.0 & 49.2 \\
\hline Over 500,000 & 3.9 & 13.0 \\
\hline \multicolumn{3}{|c|}{ Household members } \\
\hline 1 & 2.4 & 20.7 \\
\hline 2 & 1.8 & 20.2 \\
\hline 3 & 2.4 & 19.1 \\
\hline 4 or more & 4.0 & 40.1 \\
\hline \multicolumn{3}{|c|}{ Distribution of income } \\
\hline 1st quarter & 5.4 & 49.5 \\
\hline 2nd quarter & 2.2 & 20.6 \\
\hline 3rd quarter & 1.8 & 17.2 \\
\hline 4th quarter & 1.3 & 12.7 \\
\hline
\end{tabular}


Table A3: Descriptive statistics for the main sample in Table 1

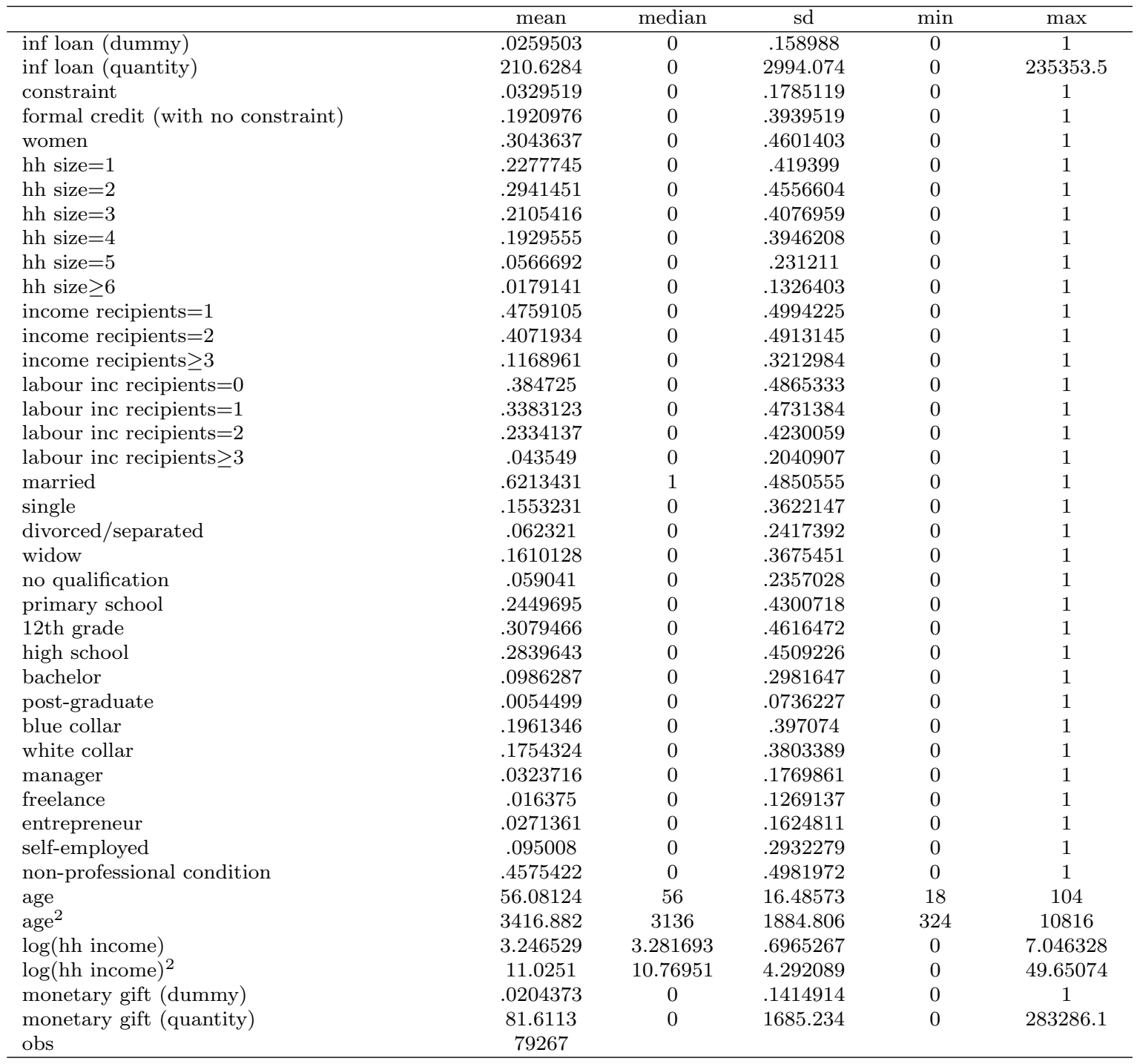


Table A4: Descriptive statistics for the sample used in Table 3, column (1)

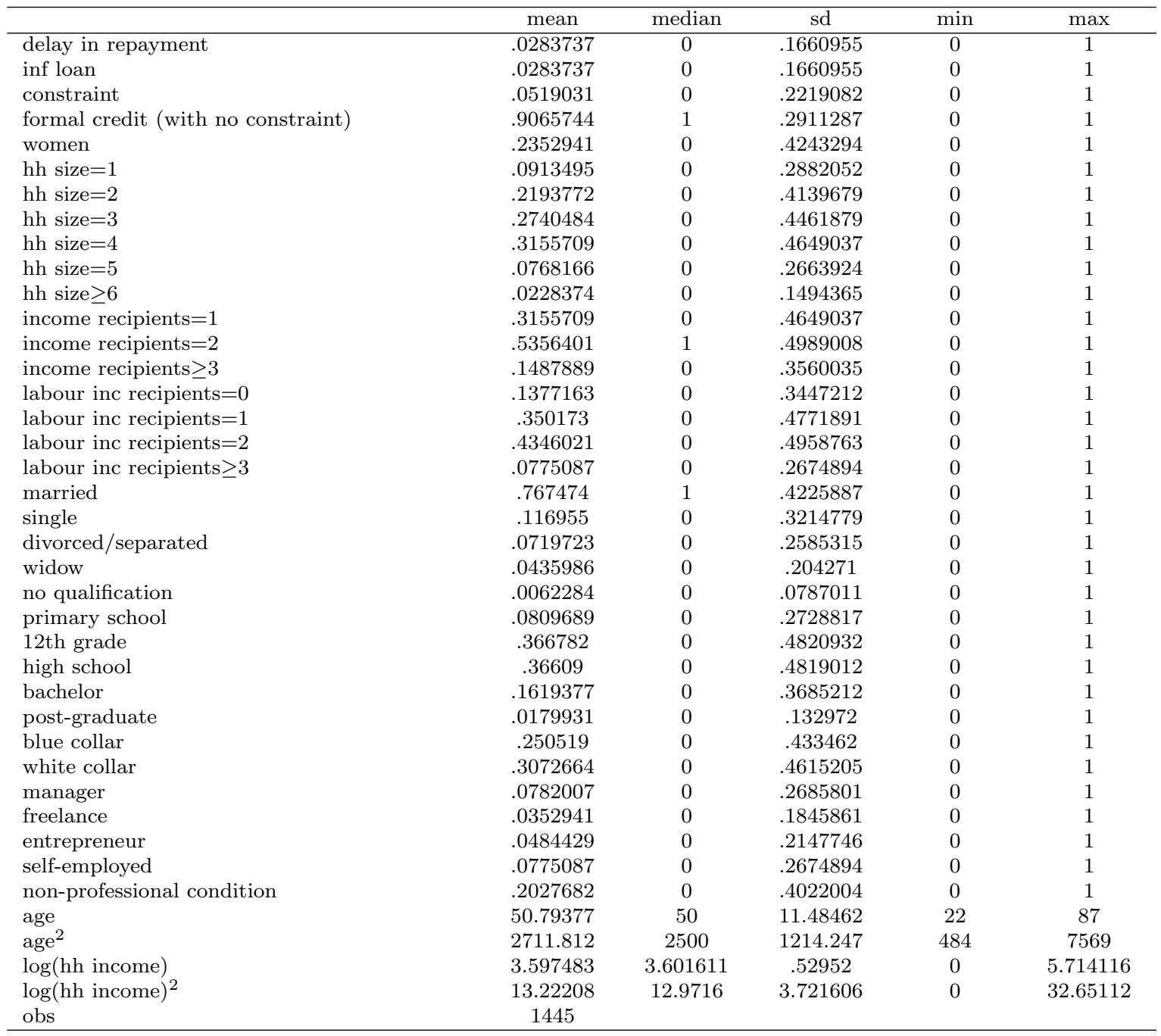


Table A5: Descriptive statistics for the sample used in Table 3, column (2)

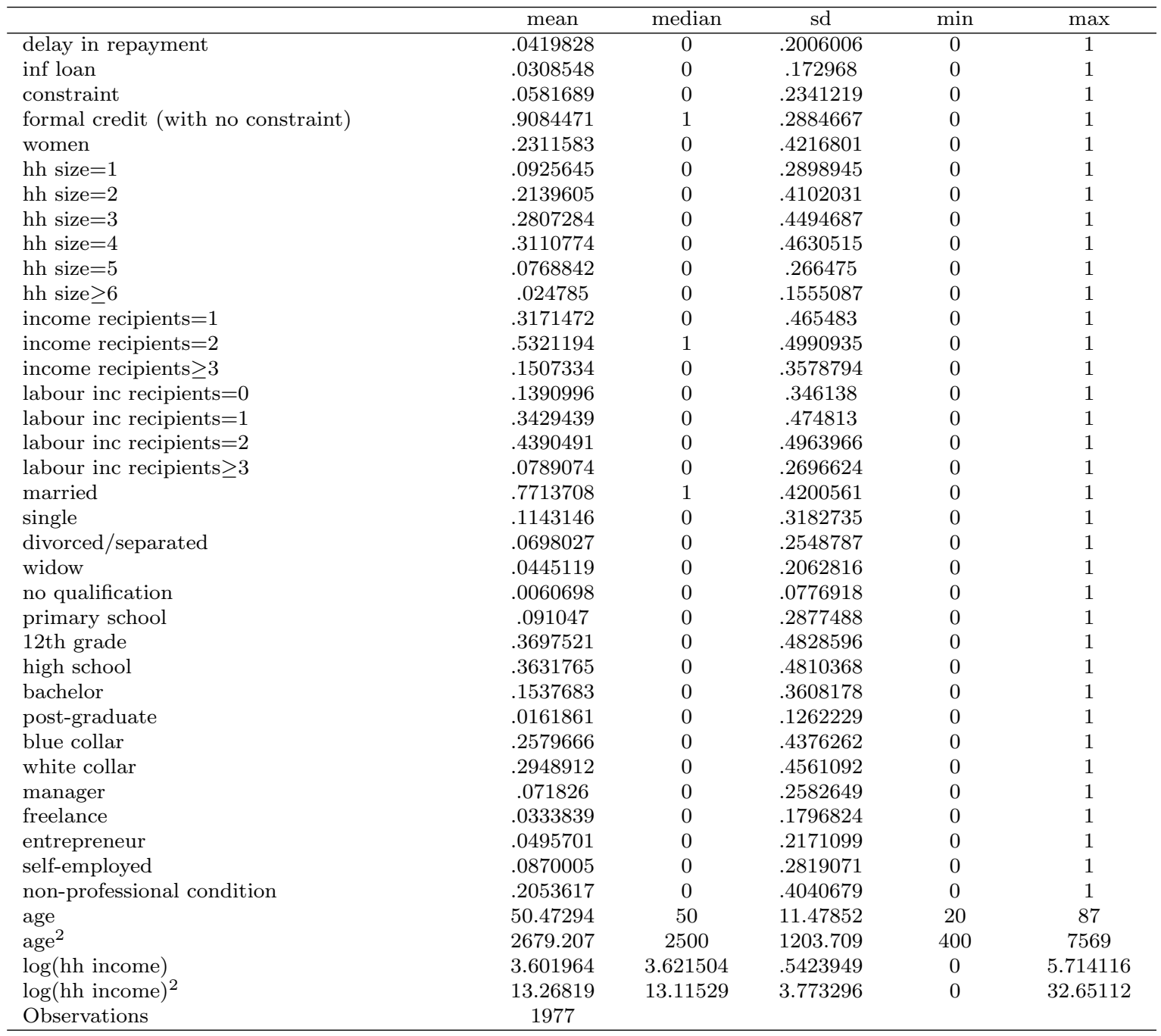


Table A6: Descriptive statistics for the sample used in Table 5, columns (2) and (3).

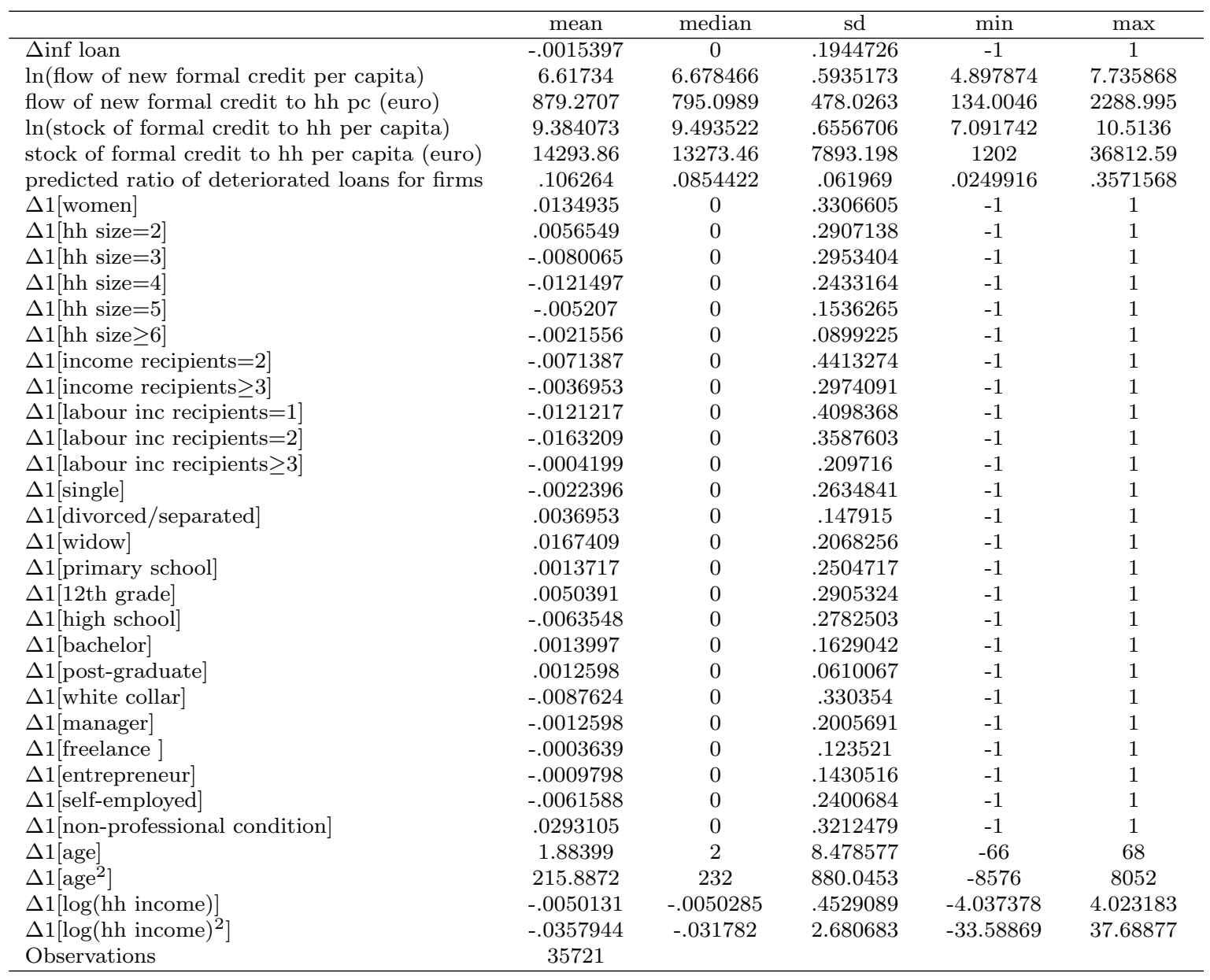




\section{RECENTLY PUBLISHED “TEMI” (*)}

N. 1073 - Search costs and the severity of adverse selection, by Francesco Palazzo (July 2016).

N. 1074 - Macroeconomic effectiveness of non-standard monetary policy and early exit. A model-based evaluation, by Lorenzo Burlon, Andrea Gerali, Alessandro Notarpietro and Massimiliano Pisani (July 2016).

N. 1075 - Quantifying the productivity effects of global sourcing, by Sara Formai and Filippo Vergara Caffarelli (July 2016).

N. 1076 - Intergovernmental transfers and expenditure arrears, by Paolo Chiades, Luciano Greco, Vanni Mengotto, Luigi Moretti and Paola Valbonesi (July 2016).

N. 1077 - A "reverse Robin Hood"? The distributional implications of non-standard monetary policy for Italian households, by Marco Casiraghi, Eugenio Gaiotti, Lisa Rodano and Alessandro Secchi (July 2016).

N. 1078 - Global macroeconomic effects of exiting from unconventional monetary policy, by Pietro Cova, Patrizio Pagano and Massimiliano Pisani (September 2016).

N. 1079 - Parents, schools and human capital differences across countries, by Marta De Philippis and Federico Rossi (September 2016).

N. 1080 - Self-fulfilling deflations, by Roberto Piazza, (September 2016).

N. 1081 - Dealing with student heterogeneity: curriculum implementation strategies and student achievement, by Rosario Maria Ballatore and Paolo Sestito, (September 2016).

N. 1082 - Price dispersion and consumer inattention: evidence from the market of bank accounts, by Nicola Branzoli, (September 2016).

N. 1083 - BTP futures and cash relationships: a high frequency data analysis, by Onofrio Panzarino, Francesco Potente and Alfonso Puorro, (September 2016).

N. 1084 - Women at work: the impact of welfare and fiscal policies in a dynamic labor supply model, by Maria Rosaria Marino, Marzia Romanelli and Martino Tasso, (September 2016).

N. 1085 - Foreign ownership and performance: evidence from a panel of Italian firms, by Chiara Bentivogli and Litterio Mirenda (October 2016).

N. 1086 - Should I stay or should I go? Firms' mobility across banks in the aftermath of financial turmoil, by Davide Arnaudo, Giacinto Micucci, Massimiliano Rigon and Paola Rossi (October 2016).

N. 1087 - Housing and credit markets in Italy in times of crisis, by Michele Loberto and Francesco Zollino (October 2016).

N. 1088 - Search peer monitoring via loss mutualization, by Francesco Palazzo (October 2016).

N. 1089 - Non-standard monetary policy, asset prices and macroprudential policy in a monetary union, by Lorenzo Burlon, Andrea Gerali, Alessandro Notarpietro and Massimiliano Pisani (October 2016).

N. 1090 - Does credit scoring improve the selection of borrowers and credit quality?, by Giorgio Albareto, Roberto Felici and Enrico Sette (October 2016).

N. 1091 - Asymmetric information and the securitization of SME loans, by Ugo Albertazzi, Margherita Bottero, Leonardo Gambacorta and Steven Ongena (December 2016).

N. 1092 - Copula-based random effects models for clustered data, by Santiago Pereda Fernández (December 2016).

N. 1093 - Structural transformation and allocation efficiency in China and India, by Enrica Di Stefano and Daniela Marconi (December 2016).

N.1094 - The bank lending channel of conventional and unconventional monetary policy, by Ugo Albertazzi, Andrea Nobili and Federico M. Signoretti (December 2016).

N.1095 - Household debt and income inequality: evidence from Italian survey data, by David Loschiavo (December 2016).

(*) Requests for copies should be sent to:

Banca d'Italia - Servizio Studi di struttura economica e finanziaria - Divisione Biblioteca e Archivio storico Via Nazionale, 91 - 00184 Rome - (fax 003906 47922059). They are available on the Internet www.bancaditalia.it. 
AABERGE R. and A. BRANDOLINI, Multidimensional poverty and inequality, in A. B. Atkinson and F. Bourguignon (eds.), Handbook of Income Distribution, Volume 2A, Amsterdam, Elsevier, TD No. 976 (October 2014).

Albertazzi U., G. ERAmo, L. Gambacorta and C. SAlleo, Asymmetric information in securitization: an empirical assessment, Journal of Monetary Economics, v. 71, pp. 33-49, TD No. 796 (February 2011).

ALESSANDRI P. and B. NELSON, Simple banking: profitability and the yield curve, Journal of Money, Credit and Banking, v. 47, 1, pp. 143-175, TD No. 945 (January 2014).

ANTONIETti R., R. BRonZINI and G. CAINELLI, Inward greenfield FDI and innovation, Economia e Politica Industriale, v. 42, 1, pp. 93-116, TD No. 1006 (March 2015).

BARdozzetTi A. and D. DotTori, Collective Action Clauses: how do they Affect Sovereign Bond Yields?, Journal of International Economics, v 92, 2, pp. 286-303, TD No. 897 (January 2013).

BARONE G. and G. NARCISO, Organized crime and business subsidies: Where does the money go?, Journal of Urban Economics, v. 86, pp. 98-110, TD No. 916 (June 2013).

BRONZINI R., The effects of extensive and intensive margins of FDI on domestic employment: microeconomic evidence from Italy, B.E. Journal of Economic Analysis \& Policy, v. 15, 4, pp. 2079-2109, TD No. 769 (July 2010).

BugAmElli M., S. FABIANI and E. SETTE, The age of the dragon: the effect of imports from China on firmlevel prices, Journal of Money, Credit and Banking, v. 47, 6, pp. 1091-1118, TD No. 737 (January 2010).

Bulligan G., M. MARCELlino and F. VenditTI, Forecasting economic activity with targeted predictors, International Journal of Forecasting, v. 31, 1, pp. 188-206, TD No. 847 (February 2012).

CESARoni T., Procyclicality of credit rating systems: how to manage it, Journal of Economics and Business, v. 82. pp. 62-83, TD No. 1034 (October 2015).

CUCINIELlO V. and F. M. SigNORETTI, Large banks, loan rate markup and monetary policy, International Journal of Central Banking, v. 11, 3, pp. 141-177, TD No. 987 (November 2014).

DE BLASIO G., D. FANTINO and G. PELLEGRINI, Evaluating the impact of innovation incentives: evidence from an unexpected shortage of funds, Industrial and Corporate Change, , v. 24, 6, pp. 1285-1314, TD No. 792 (February 2011).

DEPALO D., R. GIORDANO and E. PAPAPETROU, Public-private wage differentials in euro area countries: evidence from quantile decomposition analysis, Empirical Economics, v. 49, 3, pp. 985-1115, TD No. 907 (April 2013).

Di CESARE A., A. P. STORK and C. DE VRIES, Risk measures for autocorrelated hedge fund returns, Journal of Financial Econometrics, v. 13, 4, pp. 868-895, TD No. 831 (October 2011).

CiARlone A., House price cycles in emerging economies, Studies in Economics and Finance, v. 32, 1, TD No. 863 (May 2012).

FANTINO D., A. MORI and D. SCALISE, Collaboration between firms and universities in Italy: the role of a firm's proximity to top-rated departments, Rivista Italiana degli economisti, v. 1, 2, pp. 219-251, TD No. 884 (October 2012).

FrAtZSCHER M., D. RIMEC, L. SARNOB and G. ZINNA, The scapegoat theory of exchange rates: the first tests, Journal of Monetary Economics, v. 70, 1, pp. 1-21, TD No. 991 (November 2014).

NotARPIETRO A. and S. SIVIERO, Optimal monetary policy rules and house prices: the role of financial frictions, Journal of Money, Credit and Banking, v. 47, S1, pp. 383-410, TD No. 993 (November 2014).

RIGGI M. and F. VENDITTI, The time varying effect of oil price shocks on euro-area exports, Journal of Economic Dynamics and Control, v. 59, pp. 75-94, TD No. 1035 (October 2015).

TANELI M. and B. OHL, Information acquisition and learning from prices over the business cycle, Journal of Economic Theory, 158 B, pp. 585-633, TD No. 946 (January 2014). 
Albanese G., G. DE Blasio and P. SESTITO, My parents taught me. evidence on the family transmission of values, Journal of Population Economics, v. 29, 2, pp. 571-592, TD No. 955 (March 2014).

ANDINI M. and G. DE BLASIO, Local development that money cannot buy: Italy's Contratti di Programma, Journal of Economic Geography, v. 16, 2, pp. 365-393, TD No. 915 (June 2013).

BARONE G. and S. MOCETTI, Inequality and trust: new evidence from panel data, Economic Inquiry, v. 54, pp. 794-809, TD No. 973 (October 2014).

Beltratti A., B. BortolotTi and M. CACCAVAIO, Stock market efficiency in China: evidence from the split-share reform, Quarterly Review of Economics and Finance, v. 60, pp. 125-137, TD No. 969 (October 2014).

BOLATTO S. and M. SBRACIA, Deconstructing the gains from trade: selection of industries vs reallocation of workers, Review of International Economics, v. 24, 2, pp. 344-363, TD No. 1037 (November 2015).

Bolton P., X. FreIXAS, L. GAMBACORTA and P. E. Mistrulli, Relationship and transaction lending in a crisis, Review of Financial Studies, v. 29, 10, pp. 2643-2676, TD No. 917 (July 2013).

BONACCORSI DI PATTI E. and E. SETTE, Did the securitization market freeze affect bank lending during the financial crisis? Evidence from a credit register, Journal of Financial Intermediation , v. 25, 1, pp. 5476, TD No. 848 (February 2012).

BORIN A. and M. MANCINI, Foreign direct investment and firm performance: an empirical analysis of Italian firms, Review of World Economics, v. 152, 4, pp. 705-732, TD No. 1011 (June 2015).

BRANDOLINI A. and E. VIVIANO, Behind and beyond the (headcount) employment rate, Journal of the Royal Statistical Society: Series A, v. 179, 3, pp. 657-681, TD No. 965 (July 2015).

BRIPI F., The role of regulation on entry: evidence from the Italian provinces, World Bank Economic Review, v. 30, 2, pp. 383-411, TD No. 932 (September 2013).

Bronzini R. and P. PISELl, The impact of $R \& D$ subsidies on firm innovation, Research Policy, v. 45, 2, pp. 442-457, TD No. 960 (April 2014).

BURLON L. and M. VILALTA-BUFI, A new look at technical progress and early retirement, IZA Journal of Labor Policy, v. 5, TD No. 963 (June 2014).

Busetti F. and M. CAIVANO, The trend-cycle decomposition of output and the Phillips Curve: bayesian estimates for Italy and the Euro Area, Empirical Economics, V. 50, 4, pp. 1565-1587, TD No. 941 (November 2013).

CAIVANO M. and A. HARVEY, Time-series models with an EGB2 conditional distribution, Journal of Time Series Analysis, v. 35, 6, pp. 558-571, TD No. 947 (January 2014).

CAlZA A. and A. ZAGHINI, Shoe-leather costs in the euro area and the foreign demand for euro banknotes, International Journal of Central Banking, v. 12, 1, pp. 231-246, TD No. 1039 (December 2015).

Ciani E., Retirement, Pension eligibility and home production, Labour Economics, v. 38, pp. 106-120, TD No. 1056 (March 2016).

CIARlOne A. and V. MiCELI, Escaping financial crises? Macro evidence from sovereign wealth funds' investment behaviour, Emerging Markets Review, v. 27, 2, pp. 169-196, TD No. 972 (October 2014).

CORNELI F. and E. TARANTINO, Sovereign debt and reserves with liquidity and productivity crises, Journal of International Money and Finance, v. 65, pp. 166-194, TD No. 1012 (June 2015).

D'Aurizio L. and D. DePALO, An evaluation of the policies on repayment of government's trade debt in Italy, Italian Economic Journal, v. 2, 2, pp. 167-196, TD No. 1061 (April 2016).

DotTori D. and M. MannA, Strategy and tactics in public debt management, Journal of Policy Modeling, v. 38, 1, pp. 1-25, TD No. 1005 (March 2015).

ESPOSITO L., A. NOBILI and T. ROPELE, The management of interest rate risk during the crisis: evidence from Italian banks, Journal of Banking \& Finance, v. 59, pp. 486-504, TD No. 933 (September 2013).

MARCELlino M., M. PORQUEDDU and F. VENDITTI, Short-Term GDP forecasting with a mixed frequency dynamic factor model with stochastic volatility, Journal of Business \& Economic Statistics , v. 34, 1, pp. 118-127, TD No. 896 (January 2013).

Rodano G., N. SERrano-Velarde and E. TARAnTino, Bankruptcy law and bank financing, Journal of Financial Economics, v. 120, 2, pp. 363-382, TD No. 1013 (June 2015). 
AlESSANDRI P. and H. MuMTAZ, Financial indicators and density forecasts for US output and inflation, Review of Economic Dynamics, v. 24, pp. 66-78, TD No. 977 (November 2014).

MocETti S. and E. VIVIANO, Looking behind mortgage delinquencies, Journal of Banking \& Finance, v. 75, pp. 53-63, TD No. 999 (January 2015).

PATACCHINI E., E. RAINONE and Y. ZENOU, Heterogeneous peer effects in education, Journal of Economic Behavior \& Organization, v. 134, pp. 190-227, TD No. 1048 (January 2016).

\section{FORTHCOMING}

ADAmopoulou A. and G.M. TANZI, Academic dropout and the great recession, Journal of Human Capital, TD No. 970 (October 2014).

Albertazzi U., M. BotTero and G. SENE, Information externalities in the credit market and the spell of credit rationing, Journal of Financial Intermediation, TD No. 980 (November 2014).

BRONZINI R. and A. D'IGNAZIO, Bank internationalisation and firm exports: evidence from matched firmbank data, Review of International Economics, TD No. 1055 (March 2016).

BRUCHE M. and A. SEGURA, Debt maturity and the liquidity of secondary debt markets, Journal of Financial Economics, TD No. 1049 (January 2016).

BURLON L., Public expenditure distribution, voting, and growth, Journal of Public Economic Theory, TD No. 961 (April 2014).

CONTI P., D. MARELLA and A. NERI, Statistical matching and uncertainty analysis in combining household income and expenditure data, Statistical Methods \& Applications, TD No. 1018 (July 2015).

DE BLASIO G. and S. POY, The impact of local minimum wages on employment: evidence from Italy in the 1950s, Regional Science and Urban Economics, TD No. 953 (March 2014).

FEDERICO S. and E. TOSTI, Exporters and importers of services: firm-level evidence on Italy, The World Economy, TD No. 877 (September 2012).

Giacomelli S. and C. MENON, Does weak contract enforcement affect firm size? Evidence from the neighbour's court, Journal of Economic Geography, TD No. 898 (January 2013).

MANCINI A.L., C. MONFARDINI and S. PASQUA, Is a good example the best sermon? Children's imitation of parental reading, Review of Economics of the Household, TD No. 958 (April 2014).

MEEKS R., B. NELSON and P. AlESSANDRI, Shadow banks and macroeconomic instability, Journal of Money, Credit and Banking, TD No. 939 (November 2013).

MiCUCCI G. and P. RosSI, Debt restructuring and the role of banks' organizational structure and lending technologies, Journal of Financial Services Research, TD No. 763 (June 2010).

Mocetti S., M. PAGNINI and E. SETTE, Information technology and banking organization, Journal of Financial Services Research, TD No. 752 (March 2010).

Natoli F. and L. SigalotTi, Tail co-movement in inflation expectations as an indicator of anchoring, International Journal of Central Banking, TD No. 1025 (July 2015).

RIGGi M., Capital destruction, jobless recoveries, and the discipline device role of unemployment, Macroeconomic Dynamics, TD No. 871 July 2012).

SEgurA A. and J. SUAREZ, How excessive is banks' maturity transformation?, Review of Financial Studies, TD No. 1065 (April 2016).

ZINNA G., Price pressures on UK real rates: an empirical investigation, Review of Finance, TD No. 968 (July 2014). 